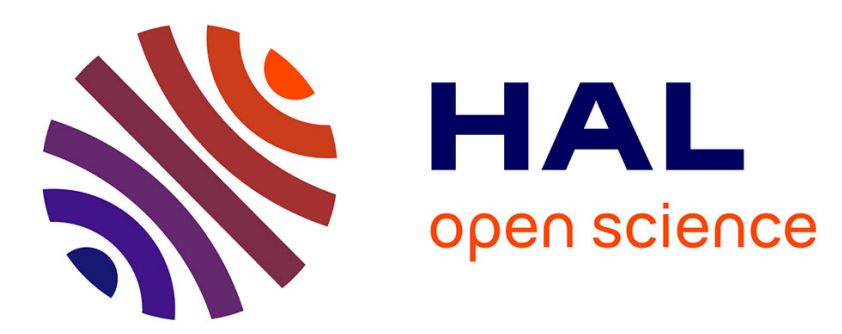

\title{
Recorded Participant Ethnography in Family Homes: Children, Social Class, and the Role of the Researcher
}

Holly Hargis

\section{To cite this version:}

Holly Hargis. Recorded Participant Ethnography in Family Homes: Children, Social Class, and the Role of the Researcher. 2020. hal-02994318

\section{HAL Id: hal-02994318 \\ https://hal.science/hal-02994318}

Preprint submitted on 7 Nov 2020

HAL is a multi-disciplinary open access archive for the deposit and dissemination of scientific research documents, whether they are published or not. The documents may come from teaching and research institutions in France or abroad, or from public or private research centers.
L'archive ouverte pluridisciplinaire HAL, est destinée au dépôt et à la diffusion de documents scientifiques de niveau recherche, publiés ou non, émanant des établissements d'enseignement et de recherche français ou étrangers, des laboratoires publics ou privés. 


\section{Recorded Participant Ethnography in Family Homes: Children, Social Class, and the Role of the Researcher}

\section{Holly Hargis}

PACTE, Université Grenoble Alpes, France.

Address: UFR SHS - Département de sociologie - 1251 avenue Centrale - 38400 SaintMartin-d'Hères

Email: holly.hargis@univ-grenoble-alpes.fr

Published reference: Bulletin de Méthodologie Sociologique, 2020, Vol. 146 37-55

\section{Résumé}

Ethnographie participante enregistrée au foyer familial : enfants, classes sociales et rôle de la chercheuse. Bien que l'ethnographie soit une méthodologie utilisée depuis des années par les anthropologues et les sociologues, peu de chercheurs ont effectué des observations aux domiciles d'enfants durant des périodes longues pour observer les socialisations enfantines et les pratiques éducatives familiales. La méthodologie discutée dans cet article permet au chercheur d'observer les socialisations enfantines en train de se faire au sein du foyer familial. Basée sur des observations ethnographiques d'une durée de sept mois au sein de quatre familles d'Ile-de-France issues de milieux sociaux contrastés, cet article revient sur la mise en place de cette ethnographie participante et enregistrée. L'article montre notamment que le chercheur est amené à tenir différents rôles dans les familles, c'est-à-dire que les conditions d'observations varient en fonction des espaces sociaux. En portant ce regard réflexif du chercheur au sein des familles, l'article fournit un premier aperçu, empiriquement documenté, de la différenciation sociale des quotidiens enfantins.

\section{Summary}

Although ethnography has been a methodology used for years by anthropologists and sociologists, few researchers have entered the homes of children for extended periods of time in order to observe childhood and childrearing practices. The methodology discussed in this article notably permits the researcher to observe child socialization among family members first-hand. Based on seven-months of ethnographic observations among four families from differing social backgrounds in the Ile-de-France region of France, the article discusses how this recorded participant ethnography was set up. The article shows that the researcher held different roles in the families and that these roles varied according to social milieu. Through first analyzing the conditions of these observations among the families, the article provides empirical evidence of the role of social class in the lives of children today.

Mots clés : enfance, langage, famille, ethnographie, classes sociales, socialisations

Keywords: childhood, language, family, ethnography, social class, socialization 


\section{Introduction}

Although ethnography has been a methodology used for years by anthropologists and sociologists, few researchers have entered the homes of children for extended periods of time in order to observe childhood and childrearing practices. In fact, the social sciences in general "have a hard time entering family daily life, an area perceived, at least in the case of modern western societies, as 'private spheres', incompatible with observations from an outsider" 1 (Lignier and Pagis, 2017: 42). This type of in-home ethnography has been perceived as overly time-consuming for the researcher and disruptive to families. Despite these difficulties, it is still surprising that this research is rare, as it is clear to social scientists that grasping the realities of child socialization is an important part of studying social stratification. As Bernard Lahire wrote, "a child's personality, their 'reasoning', and their behavior are imperceptible outside of the initial relationships they develop between themselves and the other members of their family, in a universe of objects related to different forms of intra-familial social relations" 2 (Lahire, 1995: 29).

Many studies have delved into understanding childhoods by using different methods, such as interviews with parents and children within the home or at school (to name a few: Court and Henri-Panabière, 2012; Hagerman, 2013; Lahire, 1995, 2019; Lignier and Pagis, 2017; Simon, 2018), ethnographies at school (Bettie, 2000; Calarco, 2014; Lignier, 2008; Diter, 2015), as well as quantitative methods focused on understanding daily family life (Berthomier and Octobre, 2018; Octobre et al., 2010). Other studies have set the grounds for observing socialization within the home: this research demonstrates how childhood experiences vary widely depending on the social structures in which children live (Lareau, 2011; Tudge, 2008). Yet, there still seems to be a lack of empirical ethnographic research concerning at-home child socialization, and especially in France. Because in situ observations seem to be one good way to understand first-hand how children interact with family members (and with which family members), there is still more to learn and empirical evidence to accumulate regarding socially situated childhoods.

\footnotetext{
1 « Les espaces domestiques de l'enfance sont, de façon générale, assez mal connus. Les sciences sociales pénètrent difficilement dans le quotidien des familles, souvent constitué, en tout cas dans les sociétés occidentales contemporaines, comme une «sphère privée » incompatible avec l'observation par un tiers ». (Author's translation)

2 « La personnalité de l'enfant, ses 'raisonnements' et ses comportements, ses actions et réactions, sont insaisissables en dehors des relations sociales qui se tissent, initialement, entre lui et les autres membres de la constellation familiale, dans un univers d'objets liés aux formes de relations sociales intra-familiales. » (Idem)
} 
The aim of this article is to introduce the possibility of recorded participant ethnography in family homes. The article will reflect on a seven-month ethnographic study of children in four families from varying social backgrounds in the Ile-de-France region of France ${ }^{3}$. I will show how this method permits the researcher to closely observe child socialization within the home through the conversations and activities they engage in with their family members.

\section{Childhood in the social sciences}

Over the past few years, social scientists have been more and more interested in studying childhood, a domain more traditionally studied by psychologists (Lahire, 2019; Lignier, 2019). Researchers have notably shown that child realities, child experiences, and socialization vary according to social milieu. These studies use different methods, including, for example, extensive family portraits (Lahire, 1995, 2019). Childhood has also become an interest for those who use quantitative methods: the corpus ELFE (Étude Longitudinale Française depuis l'Enfance), for example, inquires about the daily lives and socialization of 18,300 children from their births in 2011 until they turn 18 years old (Charles M.-A et al., 2011).

The ethnographic method (implying multiple reoccurring observations) focusing on the daily lives of children is rarer, especially for sociologists. Traditionally, anthropologists have been widely interested in childhoods, but these ethnographic studies have mostly focused on culture as a whole (LeVine, 2007; Lignier, 2019). However, children grow up surrounded by social structures that depend on the social positions that their families occupy. These social-class differences can be even more striking than cultural differences, as J. Tudge has shown through vast international comparisons of young children's daily lives (Tudge, 2008). Another recent and rich ethnographic study that focuses on children and their families was conducted by Annette Lareau with 12 families from varying social and racial backgrounds (2011) Lareau argues that "social class shaped a cultural logic of childrearing such that the strategies of middle-class families, both white and black, were much more in sync with the standards of dominant institutions than were the childrearing strategies of workingclass and poor families" (Lareau, 2015). Lareau's ethnography was virtually

\footnotetext{
${ }^{3}$ This research started during my graduate studies and I am currently expanding the project with 2 more years of ethnographic observations among several families during my doctoral studies.

${ }^{4}$ For a summary and commentary on this research in French, see (Pagis, 2013).
} 
unprecedented as she and several research assistants followed and took notes on children and their families for over two years, then kept in touch with the families in order to complete an original longitudinal study in 2011 (Lareau, 2011). In France, family ethnographies make up an important part of the social sciences (for recent studies see Bessière and Gollac, 2020; Blum, 2017; Gojard S et al., 2003; Grysole, 2018), but ethnographies that focus on observing childhood socialization within the home are nearly nonexistent.

\section{Focusing on conversations}

As communication between individuals is central in the organization of our societies (Simmel, in Goodwin, 1990), one way to observe child socialization within the home could be to study the conversations between family members. Studies focusing on language socialization have traditionally been used by psychologists, social linguists, and anthropologists (Miller et al., 2012; Sterponi, 2009; Tizard and Hughes, 2002; Rogoff, 1990). By observing language, researchers can take a closer look at childrearing practices, child experiences in the home, and the transmission of family codes and resources. Recorded observations could bring new material and results to childhood studies that have focused more on interviewing children and parents (and thus relying on their point of view rather than directly observing, over time, their experiences and interactions). For example, well-known sociological studies such as the work of Basil Bernstein have long shown that children learn social roles through communication (1971). For Bernstein, "as a child learns speech and thus codes which regulate his verbal acts, he learns the requirements of social structure" (Bernstein, 1971: 124). Furthermore, sociologists have demonstrated that children from different social classes inherit and mobilize different resources (including language resources) - children from upper and middle classes inherit cultural and social capital that are legitimized not only by institutions such as schools, but also by other diverse institutions, ultimately securing them high social positions within society (Bourdieu and Passeron, 1964, 1970; Lareau, 2011). By necessarily avoiding a "miserabilist" point of view (Grignon and Passeron, 1989), one must point out that this does not mean that working-class children are deprived of resources but that they interact with institutions in different ways (Willis, 1977). While some studies (notably Miller et al., 2012; Labov, 1972) highlight the complexity of working-class language exchanges between parents and children, others 
have emphasized the gap that exists between the language of working-class children and the institutions with which they interact (Bernstein, 1971; Lareau, 2011). Overall, looking at language - observing and analyzing conversations that take place at home means that one can focus on the broader codes and rituals transmitted within the family. This could help us better understand, empirically, the skills and resources children acquire at home that are unequally valued at school and in society, unveiling the "hidden" inequalities (Bourdieu and Passeron, 1970; Weininger and Lareau, 2003) of society in general.

So how can researchers observe, first-hand, child socialization in the home, and what kind of reflection and strategies on and off the field does this imply? This article will discuss the methodology of recording family conversations and participant observation in family life. By taking a reflexive approach and by discussing this methodology, we will see that the analysis also underlines the initial results of this research: I will show that the way I carried out observations and the role I held in the families varied according to the social differences between these families. To do so, I will first comment on how I set up the fieldwork, how I contacted the families, and what this implies for the study. Secondly, I will focus on the role I held and the way I carried out varied observations depending on the social backgrounds of the families. I will also expand on the ways I adapted over time to family life and, at the same time, disrupted family rhythms as an outsider. This reflexive discussion on the methodology will already give us insight on the socially-situated childhoods children experience today.

\section{Setting up the Fieldwork}

Participant observation among children "is vague and applied to research practices that are in reality, quite diverse ${ }^{5 "}$ (Lignier, 2008: 36). It seems therefore particularly necessary to discuss this method and what I mean by the terms "recorded participant ethnography."

To begin my research I first chose to focus on four families in the Ile-de-France region of France (Paris and the surrounding suburbs), choosing each family carefully in order to vary my population in terms of social characteristics - most specifically, following the findings of Lareau, according to social class. I chose each family through

\footnotetext{
5 «La notion 'd'observation participante' est vague et recouvre des pratiques de recherche en réalité très diverses » (Author's translation).
} 
my personal network of contacts, mainly in order to avoid instigating lengthy institutional approval (as would be necessary, for example, if families were selected through schools). Moreover, I believe that it was easier to successfully negotiate the observations and recordings because the families and I had a connection in some way. I was also able to carefully choose the families so that I could study two working-class families and two upper/middle-class families ${ }^{6}$. After contacting the families by phone or email, I then proceeded to conduct one - to four - hour observations with each family before, during, and after dinnertime between October 2017 and April 2018, totaling between five and six recorded observations per family (this resulted in more than 40 hours of recorded material plus field notes taken after each observation). Instead of restraining myself to a passive role, I found that it was almost impossible not to participate in family life. While this methodology was inspired by Annette Lareau's study, it differs in a few ways. First, I only observed within the home during the evenings (I did not accompany families around, and I did not conduct fieldwork at school). I also chose to speak with family members and participate in evening activities while remaining conscious of my role as a researcher. Instead of taking notes of my observations, I recorded everything. After the first visit, I asked each family if I could carry around a small recorder, telling them that this would permit me to avoid taking notes and I could participate and exchange with them in an easier way, without forgetting what happened during my visits. This recorded participant ethnography included participating with families and children in their daily lives (meaning that the researcher must also carry out an auto-analysis in their work), and efficiently acknowledging the existence of the fieldwork and the possibility of disrupting "normal" family life instead of ignoring it. This methodology implies recording speech in order to transcribe conversations and draw analyses from those recordings. I explained to each family that the recordings were only used for my research, and would not be distributed or listened to by others unless I had their approval. All families agreed to the terms of the methodology?.

\footnotetext{
${ }^{6}$ This binary comparison follows Lareau's work, but the study will be continued with several more families from varying social backgrounds.

${ }^{7}$ Even as I chose to occupy this active role among the families, I also wanted to get an idea of family life without my presence. I therefore also asked each family to record one week of dinners themselves, with a voice recorder I gave them. Three out of four families agreed, providing me with more than 15 extra hours of recorded material. I personally transcribed many of these recordings, and I transcribed all recorded observations that I had carried out myself. The extra hours of recordings will not be commented on in this article.
} 


\section{The families}

The Flores-Tesson family 8 is the first family with whom I started the observations. Ingrid Flores and Nicolas Tesson, parents of three girls, initially hired me as an English tutor for their two eldest daughters, Daniela (10 years old) and Alba (8 years old) ${ }^{9}$. They have another daughter, Rocio (5 years old). The family lives in a two-bedroom apartment in a residential middle-upper-class neighborhood in Paris. Ingrid, originally from Chile, has lived in France since 2005 and is a travel agent. Nicolas, her husband, was born in Paris and is an engineer. The family speaks mainly French together but Ingrid does speak Spanish to the girls often ${ }^{10}$. This family is an upper-middle-class family, and it can be noted that both parents have experienced upward social mobility. For purposes of comparison I will refer to this family as belonging to a global, upperclass social sphere.

The second family I contacted is the Rocher family. Jennifer Rocher is a single mother with two sons: Maxime (11 years old) and Lucas (4 years old). Jennifer is the sister of a friend of a friend of mine and lives in a northern suburb of Paris (approximately $35 \mathrm{~km}$ from Paris) in the Seine-Saint-Denis department. Her sons are half-brothers; Jennifer has full custody of Maxime, who sees his father twice a month, and shared custody of her son Lucas. Jennifer has occupied many different temporary jobs $^{11}$ and was a stay-at-home mother for a few years after Lucas was born. When she and Lucas's father split up, Jennifer took a full-time administrative position in a small firm. The Rocher family is a single-parent working-class family that lives in a mostly residential, racially-diverse ${ }^{12}$, working-class ${ }^{13}$ neighborhood, in a three-bedroom singlestory house.

The third family I visited is the Carrez family. I contacted this family through a friend who used to be a scout leader for the two eldest children. Emmanuelle and Etienne are the parents of Azilis (12 years old), Rozenn (11 years old), Mayeul (10 years old), Gaspard (7 years old), and Madeleine (3 years old) and they live in an upper-class,

\footnotetext{
${ }^{8}$ All names and some details have been changed to protect anonymity.

${ }^{9}$ I sometimes carried out observations after tutoring, but also different days of the week for the purpose of my study.

${ }^{10}$ I was able to understand most of these conversations in Spanish.

${ }^{11}$ Intérim jobs in French.

12 When I say racially diverse I am referring more specifically to my own observations paired with the percentage of immigrants who live in the city or neighborhood, since concrete racial statistics such as what exists in the United States or Great Britain are prohibited in France.

${ }^{13}$ In French I would refer to this as les classes populaires stables
} 
mostly white residential suburb close to Paris in a large two-story house with a large yard. Etienne is a doctor and Emmanuelle is a project manager for a global firm. All of the children except for the youngest, Madeleine, attend a private Catholic school in the center of Paris. This family is a practicing Catholic family with an upper-class background.

The last family I chose, a working-class family from an immigrant background, was the Chakris. I contacted this family through a school teacher who I knew through a friend. The teacher put me in contact with Amir and Nadine Chakri. Nadine, originally from Morocco, came to France in 2003 to marry Amir, who is of Moroccan descent (an arranged marriage planned by their families), and they have four children: Omar (11 years old), Aziz (8 years old), Yasmine (4 years old) and Ibrahim (3 months old). The family is a practicing Muslim family and lives in a close, racially diverse working-class suburb of Paris in the Seine-Saint-Denis French district, in a three-bedroom public housing apartment. Amir works as a janitor and Nadine is a stay-at-home mother who worked briefly in a school cafeteria before the birth of her last child. The family only speaks French together: Nadine learned French upon arrival in France (Arabic is her first language), Amir does not speak but understands Arabic, and the children understand a bit of Arabic. Table 1 summarizes this information.

Table 1: The four families

\begin{tabular}{|c|c|c|c|c|}
\hline & Flores-Tesson & Rocher & Carrez & Chakri \\
\hline & Upper-middle-class & Working-class & Upper-class & Working-class \\
\hline Mother & Ingrid, travel agent & $\begin{array}{l}\text { Jennifer, } \\
\text { employee }\end{array}$ & Emmanuelle, project manager & $\begin{array}{l}\text { Nadine, stay-at-home } \\
\text { mother }\end{array}$ \\
\hline Father & Nicolas, engineer & $\mathrm{NA}$ & Tanguy, doctor & Amir, janitor \\
\hline Child 1 & Daniela, 10 yo & Maxime, 11 yo & Azilis, 13 yo & Omar, 11 yo \\
\hline Child 2 & Alba, 8 yo & Lucas, 4 yo & Rozenn, 11 yo & Aziz, 9 yo \\
\hline Child 3 & Rocio, 5 yo & NA & Mayeul, 10 yo & Yasmine, 4 yo \\
\hline Child 4 & NA & NA & Gaspard, 7 yo & Ibrahim, infant \\
\hline Child 5 & NA & NA & Madeleine, 3 yo & NA \\
\hline Observation 1 & $10 / 10 / 2017$ & $13 / 10 / 2017$ & $10 / 12 / 2017$ & $12 / 01 / 2018$ \\
\hline Observation 2 & $19 / 10 / 2017$ & $20 / 11 / 2017$ & $20 / 12 / 2017$ & $2 / 15 / 2018$ \\
\hline Observation 3 & $5 / 12 / 2017$ & $27 / 11 / 2017$ & $28 / 01 / 2018$ & $22 / 2 / 2018$ \\
\hline Observation 4 & $11 / 12 / 2017$ & $31 / 1 / 2018$ & $11 / 04 / 2018$ & $22 / 03 / 2018$ \\
\hline Observation 5 & $3 / 4 / 2018$ & $16 / 02 / 2018$ & $10 / 05 / 2018$ & $13 / 04 / 2018$ \\
\hline Observation 6 & NA & $28 / 03 / 2018$ & NA & NA \\
\hline
\end{tabular}




\section{Contacting the families}

The contact process went quickly: I notified friends and acquaintances that I was searching for families with children between the ages of 4 and 10, roughly, because I wanted to "discover more about family life." 14 When I first contacted each of the four families (by phone or email), I explained that I wanted to "spend time with them from time to time" in order to better understand family life by observing "what happens at home in the evening and during dinnertime". I explained to them that we could meet a first time, and then continue from there and decide together "when and how I would carry out the visits." These four families were the only families I contacted and I negotiated the fieldwork with all of them separately. Each of the four families welcomed me into their homes and at their tables throughout the year, but in different ways. The social differences between the families, the differing ways I contacted them and how I carried out observations varied depending on the family and their background.

There are, of course, certain drawbacks to this method. Although I was able to choose families carefully in order to vary social backgrounds, it may have been more interesting to choose to focus on children that all attend the same school but from different social classes. Based on other researchers' experiences, I felt, however, that this would be a lengthy process to go through. Since this type of study will never be representative, using my personal network of contacts seemed to be a quicker way to recruit families and test out the ethnography. Secondly, for purposes of testing out the methodology, I chose families with children of different ages and, unlike Lareau, I did not focus on one child in the family. This meant that I was sometimes overwhelmed with material and could not necessarily compare one child's experiences to another's ${ }^{15}$. Finally, I visited the families over a period of seven months. In order to finely observe child socialization, ethnographic observations should be carried out over an extended period of time.

\footnotetext{
${ }^{14}$ My translation. For the purpose of this article I have translated all citations and excerpts from French to English.

${ }^{15}$ Retrospectively it would have been interesting to focus on a "target" child of the same age in each family (Lareau, 2011). I have therefore decided to continue this study by recruiting new families and focusing on 5year-old children.
} 


\section{My role as a participant observer}

I cannot deny the fact that my role as an observer, in some way, disrupts normal family rhythms. I also cannot expect that I will be able to observe exactly how family life proceeds as if I were not present: the families will always know that I'm around and my presence will always have an impact on the individuals I spend time with. Because of this, I have decided to fully assume my role as an observer and thus I became a participant observer. Instead of looking on and taking notes, I decided to participate actively in family life, in order to make a place for myself among these families. I felt that this would be a more efficient way to observe. This is also why I decided to record my observations: I felt that the audio recorder was not very noticeable (therefore less disruptive than note taking or video recording), and this meant that I could listen to and transcribe all observations, to focus my analyses through conversations. I quickly realized that my place as a participant observer was quite easy to take on: negotiating the visits was limited to just a few minutes of exchanges, or a few text messages or emails. In fact, since I would come over to "hang out" with the families, there were not many questions asked about my purpose there. Neither the parents nor the children asked to speak about the purpose of the study for more than a few minutes in any of the families. This was probably due to the fact that I was not seen as very intrusive, being a young, foreign woman, and because the families and I had a friend in common ${ }^{16}$.

Overall, because I used my personal network of contacts, negotiating the fieldwork was less time-consuming than I had expected, and there were rarely hesitations regarding my presence within the homes. This is also likely related to my social characteristics as well: a man, or maybe even a Parisian, could have had a harder time entering the lives of these families. The fact that I am from the United States and am a young, white, female student in my mid-twenties who has lived in France for several years (and most of my adult life), speaks the language, and is familiar with the culture is important to note, as these attributes helped and influenced my acceptance into these families. I was, just as Katherine Throssell has underlined in her own research, notably an "outsider," able to make mistakes and "ask silly questions" making myself an "unusual

\footnotetext{
${ }^{16}$ The only family that hesitated when I asked them if I could return to visit occasionally was the Chakri family (Nadine, the mother, needed to ask her husband's permission). This seemed to be related to the fact that Amir, the father, was the main authority in the family and that I mostly interacted with Nadine. It also could have been because the son's teacher recommended me to the family, and at first I was seen as related to the school. But after the second visit, it became quite usual for me to stop by, Thursday afternoons. Nadine mentioned many times that I could come over anytime, and that she enjoyed "chatting with me."
} 
adult, one who inspired sympathy (or perhaps even pity) at times" (Throssell, 2018). For example, all four mothers commented on the fact that my own family lived quite far away and that I could come over anytime in order to share a meal and spend time with their family. Being foreign, which is mainly noticeable by my accent in French and some language mistakes, made me seem less intrusive as the families perceived me as trying to find out more about French life and French families from an outside perspective, which gave legitimacy to my study, or, at least in my view, easier access to private family life. It should also be noted that I felt quite comfortable in all of the families from different social milieus and felt that I could make tight connections with them, as I come from a large working-class family ${ }^{17}$ but currently am in daily contact through my studies with the upper-class world highly equipped with cultural capital. I will next expand on this point, showing how the social backgrounds of each family meant that my role as a researcher - the way I was perceived and welcomed in the families - varied. Furthermore, this meant that the methodology, thus the way I interacted with the families, varied according to these differing social spaces.

\section{Places and Spaces: socially-situated roles among the families}

The way I negotiated the fieldwork and the role I held in these families were socially situated. This meant that the observations I carried out were not done so in exactly the same way - it depended on the social backgrounds of each family. All of these families are quite different from one another, but I found a pattern to the different places that I held in the upper-class homes and the working-class homes. In the two upper-class families (where at least one of the parents occupied a profession considered as cadre or professions intellectuelles $^{18}$, requiring five years of higher education), my presence was not unusual and my relationship to the parents and the children was formed through organized activities, as family time in these homes was strongly adapted to the children. However, in the working-class families, my presence was quite out of the ordinary and my relationships with the children and the parents were formed separately, as a stronger difference between the child world and the adult world existed in these homes. This meant that who I spent time with, what I observed, and the way I observed varied

\footnotetext{
${ }^{17}$ While growing up my father worked as a drill rig operator for roads and my mother was a stay-at-home mom (I am the oldest of four children).

${ }^{18}$ This is based on the classification of professions in France (the PCS system by INSEE), for more information see (Desrosières and Thévenot, 2002).
} 
among the families. In an ethnography of this type, the way the researcher participates and observes must differ, and discussing this point further already gives us an idea of the socially situated realities that children live in today in France.

\section{The adult world and the child world: between adaptation and distinction}

In the family home there is a clear difference between parents (adults) and children. The spaces that these family members occupy in the home, however, depend on social contexts. This meant that the space I was given in the families also varied. In the working-class families, the mothers - Jennifer and Nadine - spent a lot of time talking directly with me during the visits, without their children. These mothers dedicated time to chat about their lives, often informing me about the practical aspects of parenthood, their experiences in the past with the births of their children, their jobs, and especially money and how they spent it on their children. When Nadine and Jennifer asked about my school the questions were very practical - for example, how I financed my studies and where I lived. For Jennifer and Nadine, the working-class mothers, I became a confidant and we spent a lot of time talking together; children were not made explicitly a part of these "adult" conversations.

For example, when I arrived at the Chakri house, Nadine usually insisted that I greet the children (who were often playing in their rooms upstairs) quickly and then come back down to talk and drink coffee with her. This meant that if I wanted to go see what the kids were doing while playing upstairs, I would ask Nadine if that was okay, or I waited until she was busy (moments when she was on the phone, taking care of her infant son, etc.). This meant that the time I spent at the Chakri house was often divided between time spent with Nadine in the early afternoon and time spent hanging out with the three children in the boy's room until dinner when the whole family ate together and usually watched TV afterwards. These were observational strategies that I had to take on (going to see the children for example), that weren't necessary in upper-class homes.

My interactions at the Rocher house were similar, and I tried to arrive earlier in the afternoon with these families in order to have time to "hang out" with the moms and then the children. Jennifer often offered me a beer before dinner (while she cooked) and we would chat while the children were watching TV or playing in their rooms. I would take advantage of moments when Jennifer was busy to go then hang out with the children. One time Jennifer suggested that we could all (Jennifer, Lucas, and I, while 
Maxime played videogames in his room) play with Lucas, 4 years old, before dinner. After playing Legos and Playmobiles together for about 15 minutes, Jennifer eventually left us both to play together while she took care of housework (for about 20 minutes after that).

It was clear that in these families the adult world seemed, in fact, in close contact but separated from children, as adults were often around their children at home but didn't explicitly and constantly adapt their activities to them (or, at least, much less than in the middle/upper-class families). During my time visiting the working-class families, these parents considered me as an adult, didn't encourage me to go play with the children, and hardly asked the children to show me things in the house. This did not mean, however, that parents found children's activities inconsequential (on the contrary, both mothers spoke a lot about their children to me), but more that there existed a certain separation between the adult world and the child world in these homes. This seemed to be related to the living conditions and daily rhythms of these workingclass families. For example, Amir Chakri often spent one to two hours grocery shopping several afternoons of the week, looking for discounts. Nadine, a stay-at-home mother with three children and a newborn, spent a great amount of time cleaning the house and preparing food in the evenings. I was never asked to help with these activities (and when I offered to help out with anything, both mothers usually refused). Nadine spent lunchtime and the afternoons and evenings with her children every day; my visits were an opportunity for her to confide and talk with someone else ${ }^{19}$. Jennifer Rocher also spent a lot of her free-time taking care of her boys. But these mothers never asked or expected me to help with the children. There was only that one time when Jennifer asked if she could "take advantage" of my visit by asking me to play with Lucas in his room while she tidied the house and prepared dinner.

My role in the upper-class families was quite different. The parents perceived me as a young, foreign research student and didn't hesitate to ask for my involvement in multiple organized family activities at home. These parents also explicitly adapted their activities towards their children. Each weeknight Emmanuelle Carrez helped her sons Mayeul (10 years old) and Gaspard (7 years old) do their homework, asked them to memorize and recite their daily lessons, and also created extra homework for them.

\footnotetext{
${ }^{19}$ Gender plays an important role here too. As a woman I held a specific role in these families that would have been quite different if a man was conducting this ethnography.
} 
Emmanuelle almost always explicitly asked for my involvement in these evening lessons. Both Carrez parents also asked at each visit that I read a bedtime story to Gaspard and Madeleine, an activity that often took up to 30 or 45 minutes for each child. In these families, what I was able to observe largely depended on what the parents or the children invited me to participate in, and their guidance greatly shaped the conditions of my observations. For the Flores-Tesson family, weekly at-home activities were also supervised by parents and I was made a part of these moments as well. The girls were not allowed to watch television on weeknights and often practiced piano and read silently before going to bed. The girls played the piano "for me" after dinner, showing me what they were working on that week. Before bedtime, their parents would question them on what they were reading and they would show me their books. Sometimes, when Rocio Flores-Tesson, 5 years old, begged me to continue playing, I had to insist multiple times that it was late and time for me to go home (and for her to go to bed). Parents in these families gave me a babysitter type role, and never once commented or led the children to believe that they could be "bothering" $\mathrm{me}^{20}$. In the working-class families, both Jennifer and Nadine seemed to understand that I wanted to learn more about family life and their children, but several times both asked their children not to "bother" me too much.

While I noted a separation between the adult and child worlds in the workingclass families, this doesn't mean that I had less interaction with these children. The conditions of the observations were simply different: after chatting with the mothers for some time, I would then ask to go see what the children were doing (instead of being instructed by the parents or the children, as in the middle-class families). In the working-class families, Yasmine Chakri (4 years old) and I played games and practiced writing and drawing, for example, and I watched Omar and Aziz Chakri play video games, they showed me music videos online, and we even started writing a story online together (this was their idea). I watched TV and movies with Maxime and Lucas Rocher. Parents were always aware of these activities, and the children had to ask in advance for permission. In the upper-class homes, the observations were carried out differently. Ultimately, family activities were adapted to the children in these upper-class families,

\footnotetext{
${ }^{20}$ During one dinner, when Rocio was climbing on me while we were eating, Rocio's mom did say to her that "all Holly wants to do is to eat her lasagna in peace ... tomorrow I'm going to do the same thing to you, touch your hair while you're eating (everyone laughs)! It's unbearable (laughs)!" (Observation n ${ }^{\circ}$ ). This was said in a joking way and Ingrid never told Rocio directly that she could be bothering me.
} 
and I was a resource for the parents and for the children: participating, helping, assisting, observing, and conversing with all the members of the family in an educational way.

My role as a researcher was socially situated, and the way I observed - what activities and conversations I participated in - varied greatly according to the social backgrounds of these families. In different milieus "child culture is unequally distanced from adult culture" and "children's roles" are defined differently in terms of skills and knowledge that varies depending on social structures ${ }^{21 "}$ (Lignier et Pagis, 2017: 51; Chamboredon and Prevot, 1973). This meant that I needed to have strategies on the field that varied and were flexible. I needed to be able to accept, for example, the fact that spending 45 minutes reading to Gaspard Carrez would be part of my observations, and take into account that I would maybe miss out on other interactions between other family members. This meant that the time spent on the field varied between families as well, ultimately meaning the way I observed and interacted with the families depended on their daily rhythms and perceptions of family life.

\section{An ethnographer's presence: more or less unusual}

Because I observed and participated in family life, I cannot deny that this disrupts normal family rhythms. However, the way I "disrupted" and "adapted" to these families' daily lives varied, just like, as we saw, my role varied among the families. Through the conversations that we had and that I observed, I will next comment on how my presence changed daily family life through the conversations I observed and participated in.

In the upper-class families, unlike in the working-class families, my presence was not particularly unusual. These families were used to having people over at their houses, and the children were used to interacting with adults from the many extracurricular activities they were involved in. This finding is not very surprising, as it is well known that children from middle- and upper-class families participate in "multiple activities orchestrated by adults" (Lareau, 2011), activities that are often perceived as helpful to developing children's "social skills (interacting and working with others)" (van Zanten, 2009). My role as Daniela and Alba Flores-Tesson's English tutor already shows that my presence as an ethnographer in the family was simply an extension of my habitual English lesson with the girls (and I was not the only young tutor who came weekly to the

\footnotetext{
${ }^{21}$ La culture enfantine « est inégalement éloignée de la culture adulte » (Author's translation)2017.
} 
apartment). These girls were therefore used to interacting with other adults and children outside of school on a weekly basis. For the Carrez family (the other upper-class family) my visits to the house were special, but not extraordinary either. All of the children interacted with university students through scouts and at church, and other young adults had been invited to dine in their home. My presence as an ethnographer in these two upper-class families was certainly particular, but not by any means unusual.

However, other than at school, working-class children are rarely placed in repetitive weekly situations where they talk and interact with adults other than their parents or extended family members, at least much less than children from middle- and upper-class homes (Lareau, 2011). Maxime and Lucas Rocher, for example, don't participate in any extracurricular activities. For Jennifer, a single, working-class mother, these activities are difficult to organize and expensive. Jennifer explained to me that she didn't want to have to "pay the fees" for a sports activity, especially because Maxime would only be able to attend half of the practices on Saturday, since every other Saturday he stays with his father. Jennifer also mentioned that she preferred that Maxime "focuses on school" and that in any case he "didn't like to play rugby". Like the Rocher children, the Chakri children do not participate in any extracurricular activities except for Aziz, who plays rugby in a free local sports club. Aziz talked a lot about rugby, and this activity seemed central in the family's weekly organization. The Chakris mentioned to me multiple times that Tuesday was a "busy night, no time for play or TV, just rugby, dinner, and bed." For the upper-class families, these financial and organizational constraints simply did not seem to exist; in fact, parents in both families talked about additional activities the children could do without mentioning the costs 22 . In addition, the organization of these activities in the upper-class homes was often delegated to others; a full-time nanny was employed by the Carrez family and a weeknight babysitter worked for the Flores-Tesson family.

For the upper-class children, speaking and interacting with adults other than their parents or teachers was therefore a daily activity. The upper-class children spoke freely and directly to me, asking me many questions and keeping close contact with me throughout my visits and from the very first visit. In these families, both the parents and

\footnotetext{
${ }^{22}$ Except for one time, when Emannuelle Carrez did explain to me that they had stopped renting a violin for Azilis and had finally bought her one, which is "expensive but necessary for someone who studies in a conservatory."
} 
the children involved me in their conversations and activities by, for example, clarifying family discussions for me.

\section{Excerpt 1: The Carrez family, observation $n^{\circ} 2$ \\ Dinner, Sunday evening}

Tanguy, father: So you went to the park?

Mayeul, 10 yo: Well yeah, 2, 3 minutes!

Tanguy: To play a bit? You played soccer?

Mayeul: No, we played décrochedécroche.

Tanguy: Décrochedécroche.

Azilis, 13 yo: Ahhh (talking to the researcher, $\mathrm{HH}$ ) it's a thing, you know, everyone is attached to another person, there's a cat and a mouse who run around, and the mouse can pass through the middle of the circle, and ummm, the idea is that when the mouse is a little tired, it can attach to another person and...

Gaspard, 7 yo: (talking at the same time as Azilis) This is the circle, and here, in the middle, instead of continuing like this, the mouse goes like this, you see? (Showing HH with gestures.)

Both Azilis and Gaspard jumped in at the first chance they had to explain to me the game that Mayeul had played earlier in the day. In general, most members of these two upper-class families perceived my presence as a learning experience, one where I could learn about family life, and French life specifically, even "French traditions" as the Carrez parents often mentioned. Daniela and Alba Flores-Tesson, for example, corrected a mistake in French that I had made during my second visit (something that was common with all the upper-class children I visited and that never happened when I was among the working-class children). As Alba even stated enthusiastically, I had "already learned something" during this visit.

On numerous occasions, the upper-class parents also asked their children to show me things, such as when Nicolas Tesson asked his daughter Rocio, 5 years old, to show me her missing tooth, or when Emanuelle Carrez, on the first visit, just seconds after my arrival (and I had not met the family yet, only spoken to Emanuelle on the phone), instructed Madeleine, 3 years old, to show me her room and how she put on her pajamas. In the Carrez family, Emmanuelle often explicitly encouraged her children to explain to me what they were doing or to give me their advice:

\section{Excerpt 2: The Carrez family}

During the first observation, Emmanuelle asks her son to explain to me their weekly rhythm: 
Emmanuelle, mother: So, and, and, Mayeul, what goes on at home, weekday evenings, the nights where the next day you have to go to school?

During the third observation, Azilis talks with her mother

Azilis, 13yo: Oh, Mom, I made mendiants! (A chocolate cookie with nuts and fruit.)

Emmanuelle: Very good, and does Holly know what a mendiant is?

During the fourth visit:

Emmanuelle: Okay kids, you need to tell Holly what you liked visiting in Rome, alright? Because she is traveling there with her parents. And did you tell her where you are going this year on vacation?

Conversely, in the working-class homes, weeknights were primarily devoted to unorganized family time. The children often watched TV, played games, and spent time with parents and siblings before and after dinner. My presence was especially unusual because these families did not often have visitors over at the house. I was in fact the only visitor at the Chakris' since they had moved into their apartment two years before (other than Amir's mother and a neighbor who stopped by once after Ibrahim was born). The children did not directly question me about my personal life, and their parents didn't encourage them to do so either. For example, Maxime Rocher, 10 years old, asked me only during my third visit where I was from, and his mother, Jennifer, answered for me. Maxime, in general, rarely asked me questions directly:

\section{Excerpt 3: The Rocher family, observation $\mathrm{n}^{\circ} \mathbf{1}$}

We are all in the living room just after dinner, Maxime is watching TV while Jennifer talks to me on the couch:

Maxime, 11yo: (to his mother) When is Holly leaving?

Jennifer, mother: Well, I don't know!

Maxime: Will she sleep here?

Jennifer: (laughing) I don't know, what's up with these questions?

Maxime: (in a joking manner) She could sleep here and you could sleep on the couch! Jennifer: (laughing) Well that would be nice (sarcastically and playfully), wouldn't it?!

During this first visit, Maxime invited me, in an indirect and jokingly way, to stay over the night. The exchange between Jennifer and Maxime relating to my presence was very short, and it seemed in this family that it was up to me to set the grounds of the observations (while in the upper-class families I was instructed, by parents and children, on where to go, what to do, and what to see). Maxime didn't really seem to understand exactly why or how long I would stay, as he demonstrated by imagining that I could 
maybe even stay the night. We can also see that Maxime didn't address this question to me directly, and even at the end of my visits rarely spoke to me (or, at least, much less than the upper-class children). It is important to note that although Maxime seemed particularly shy (at least around me) his mother didn't encourage him to talk to me specifically, or to intervene in discussions, especially during dinnertime:

\footnotetext{
Excerpt 4: The Rocher family, observation $n^{\circ} \mathbf{1}$

We are eating salmon for dinner and talking about the family's general daily rhythm during the first visit

Jennifer, mother: What kinds of fish have I bought recently, white fish, uhh (pause)

HH: Cod?

Maxime, 11yo: Breaded fish!

Jennifer: (she cuts off Maxime) Yeah cod, salmon, salmon's good, breaded fish, we buy all that at Lidl and it's not that expensive (Jennifer and I continue talking about the grocery store Lidl)
}

Jennifer did not ask her son to weigh in on the matter of what she buys at the grocery store, and even cut him off when he added a comment. I observed a strong asymmetry between children and adults in working-class families, where parental authority dominated family life and children were rarely invited to share their opinions or, for example, negotiate, as Lareau notably demonstrated (2011).

In the Chakri family I observed and participated in a similar way. The Chakri and Rocher children were particularly shy in front of me during my first visits (and then opened up more after two or three visits). My presence in all families changed the dynamics of daily family life, but while the children in the upper-class families guided me (at their parents request and by their own initiative) through conversations and around their daily lives, this was less present in the working-class homes.

In the upper-class families, some children were more shy than others, but all children were encouraged by their parents to interact directly with me, and even the most shy upper-class children directly asked me questions during the first visits, with and without parental guidance (see Rogoff, 1990, for more). For example, although Rozenn and Gaspard Carrez were much less talkative (at least at home, when I was present) than their siblings, they started many conversations with me. In the working class families, this sort of behavior was not encouraged, even if the children did directly speak to me: 


\section{Excerpt 5: The Chakri family, observation $\mathrm{n}^{\circ} \mathbf{1}$}

We are all eating dinner at the dinner table and Nadine is talking to me about the trip the family took to Morocco the year before. Without being asked by their parents, Omar and Aziz start telling a few stories about the trip.

Nadine, mother: (to me) It's nice to talk because my kids they're not usually like this (laughing)!

Aziz, 8 yo: Because, because you guys never talk to us! You don't talk with us!

Nadine: Because Dad, he doesn't like to talk.

Amir, father: There's a time for talking, there's a time for talking!

Aziz: Well yeah there's a time!

Nadine: The weeeekennnnd! But not during the week.

Omar, 11 yo: (to me) You, you, wait, could you ask us questions? About History?

HH: Ahh ok! So you want me to ask you a history question...a general one or about French history? Which one do you want?

Omar: Ehhh, the history I learned is French history.

Aziz: Yes, France.

HH: Ok, tell me a bit about the French Revolution!

Omar: The French Revolution it's, well there was Bastille (he continues to explain for a few minutes).

Aziz: (When Omar finished) And me, can someone ask me a question? About the police force? I know everything!

Omar and Aziz seemed particularly excited that a young student was interested in their family life. My role in the family seemed particularly disruptive, as I observed that talking at the dinner table or during the TV series the family watched each night was restricted by their father, Amir (who seemed annoyed when the children asked me questions at dinnertime). However, as the visits continued the family became more and more used to my presence, and I found myself more and more ingrained in their daily routine after each observation. During the last observations, dinnertime was quicker and conversations were scarce or solely between the parents, because I was more adapted to the family, and the children knew that it was no longer such an exception for me to be there (and so talking at the dinner table was no longer tolerated during my visits, like it had been during the first two observations). As Nadine put it during my last visit, I was "used to the way things worked" in their home.

Through this recorded participant ethnography I was equipped with multiple tools to start understanding the relationship between parents and children and more specifically the role of conversation within the household. It was clear that upper-class children and working-class children were not exposed to the same type of language practices within the home, and that upper-class children were explicitly encouraged by 
their parents to express themselves verbally while this was not an explicit value in working-class homes, where parents did not adapt their conversations to children, and where children were held to higher and more direct parental authority. This all meant that my strategies, role, place, and the way I adapted to family life differed greatly according to the social backgrounds of the families. This was also something that was constructed over time, which is why continuing observations over a longer period of time seems necessary for this type of study.

\section{Conclusion}

All four families in this study are very different, and my experiences in each family were, of course, unique. To conclude, this recorded participant ethnography was, firstly, experimental. Its binary approach has advantages (in contrasting social structures) and limitations (often leaving out important differences and details within social classes and neglecting other aspects of social structure such as immigration, race, and gender), and deserves to be explored further and paired with other studies. Ethnographies of this type (reoccurring observations over time) could be useful to pair with studies that use other methods that focus on the points of view of children and parents, as well as statistical methods ${ }^{23}$, since studying "the gap between local observations and statistical correlations would advance our understanding of these local events as well as the importance of categorical statistic classification ${ }^{24 "}$ (Weber, 1995: 5). To better understand the social inequalities and disparities that exist among adults, we must look further into the roles that children hold among their families, roles that vary greatly and that have direct consequences on children's relations in society and more specifically in the institutional world. This is why ethnographic research focusing on at-home childhood experiences is a method that deserves to be explored further. Ultimately, proceeding with this type of ethnographic methodology allows the researcher to observe socialization firsthand, something that has been traditionally explored by anthropologists (see LeVine, 2007) and that deserves more attention in modern sociology.

\footnotetext{
${ }^{23}$ See the longitudinal study being carried out in France: Étude Longitudinale Française depuis l'Enfance (ELFE), https://www.elfe-france.fr/

24 "L'écart entre observations locales et corrélations de variables statistiques doit pouvoir faire avancer à la fois la compréhension des événements à l'échelle locale et la pertinence des catégories de classement statistique" (Author's translation).
} 


\section{Acknowledgments}

I would like to thank Julie Pagis for her direction and support of this research from the beginning, as well as Alice Simon and the Bulletin de méthodologie sociologique for their feedback. I would also like to show gratitude to Phoebe Mogharei for her comments that greatly improved the written manuscript.

\section{References}

Bernstein B (1971) Class, Codes, and Control: Theoretical Studies towards a Sociology of Language, New York: Schocken Books.

Berthomier N and Octobre S (2018) Primo-socialisation au langage : le rôle des interactions langagières avec les parents durant les 365 premiers jours de l'enfant d'après l'enquête Elfe, Culture études, 2 (2): p. 1-20.

Bessière C and Gollac, S (2020) Le genre du capital : comment la famille reproduit les inégalités. Paris : La Découverte.

Bettie J (2000) Women without Class: Chicas, Cholas, Trash, and the Presence/Absence of Class Identity, Signs, 26 (1): 1-35.

Blum P (2017) Un quotidien ébranlé. Des jeunes patients de la psychiatrie et leur famille, dans la France contemporaine. PhD thesis, ENS, Paris.

Bourdieu P and Passeron J-C (1964) Les Héritiers : les étudiants et la culture, Editions de minuit

Bourdieu P and Passeron J-C (1970) La Reproduction, éléments d'une théorie du système d'enseignement, Editions de minuit.

Calarco J (2014) Coached for the Classroom: Parents' Cultural Transmission and Children's Reproduction of Educational Inequalities, American Sociological Review, 79 (5): 1015-1037.

Chamboredon J-C and Prevot Jean (1973) Le " métier d'enfant ». Définition sociale de la prime enfance et fonctions différentielles de l'école maternelle, Revue française de sociologie, 14 (3): 295-335.

Charles M-A, Leridon H, Dargent P, Geay B et l'équipe Elfe (2011) Le devenir de 20000 enfants. Lancement de l'étude de cohorte Elfe. Population et Sociétés 475: 1-4.

Court M and Henri-Panabière G (2012) La socialisation culturelle au sein de la famille : le rôle des frères et sœurs, Revue Française de Pédagogie, (179): 5-13.

Desrosieres A et Thevenot L (2002) Les Catégories socioprofessionnelles, Paris, La Découverte.

Diter K (2015) « Je l'aime, un peu, beaucoup, à la folie... pas du tout ! ». La socialisation des garçons aux sentiments amoureux, Terrains \& travaux, (27): 21-40

Goodwin M (1990) He-Said-She-Said: Talk as Social Organization among Black Children, Indianapolis: Indiana University Press.

Grignon C and Passeron J-C (1989) Le savant et le populaire : Misérabilisme et populisme en sociologie et en littérature, Paris: Le Seuil.

Gojard S, Gramain A, Weber F (sous la direction) (2003) Charges de famille : dépendance et parenté dans la France contemporaine, La découverte.

Grysole A (2018) Placer et déplacer ses enfants. Stratégies transnationales de mères sénégalaises aux Etats-Unis, en Italie et en France, PhD Thesis, Paris, EHESS. 
Hagerman M (2013) White families and race: colour-blind and colour-conscious approaches to white racial socialization, Ethnic and racial studies, 37 (14): 2598-2615.

Labov W (1972) Language in the Inner City, Philadelphia: University of Pennsylvania Press.

Lahire B (1995) Tableaux de famille: Heurs et malheurs scolaires en milieux populaires, Gallimard/Le Seuil.

Lahire B (2019) Enfances de classe : de l'inégalité parmi les enfants, Seuil.

Lareau A (2011) Unequal childhoods: class, race and family life. Second edition with an update a decade later, Berkeley: University of California Press.

Lareau A (2015) Cultural Knowledge and Social Inequality, American Sociological Review, 80.

LeVine (2007) Ethnographic Studies of Childhood: A Historical Overview, American Anthropologist, 109 (2): 247-260.

Lignier W (2008) La barrière de l'âge. Conditions de l'observation participante avec des enfants, Genèses, 4 (73): 20-36.

Lignier W (2019) Prendre, Naissance d'une pratique sociale élémentaire, Seuil.

Lignier W and Pagis J (2017) L'enfance de l'ordre : comment les enfants perçoivent le monde social, Seuil.

Miller P, Cho G, Bracey J (2005) Working-Class Children's Experience through the Prism of Personal Storytelling, Human Development (48): 115-135.

Octobre S, Détrez C, Mercklé P, Berthomier N (2010) L'enfance des loisirs. Trajectoires communes et parcours individuels de la fin de l'enfance à la grande adolescence. Ministère de la Culture - DEPS, «Questions de culture ».

Pagis J (2013) Une ethnographie des socialisations enfantines, Genèses, (93): 176-183.

Rogoff B (1990) Apprenticeship in Thinking: Cognitive Development in Social Context, New York: Oxford University Press.

Simon A (2018) Les catégorisations enfantines de la politique, Politiques de communication, 1 (10): 193-223.

Sterponi L (2009) Accountability in Family Discourse: Socialization into norms and standards and negotiation of responsibility in Italian dinner conversations, Chilhood, 16 (4): 441- 459.

Throssell K (2018) In the Mouths of Babes: A Discussion of the Use of Semidirective Projective Interviews with Children, Bulletin of Sociological Methodology issue 137-138: $25-44$.

Tizard B and Hughes M (2002) Young Children Learning, Blackwell publishing. Tudge J (2008) The Everyday Lives of Young Children, Cambridge University Press.

van Zanten A (2009) Le travail éducatif parental dans les classes moyennes et supérieures : deux modes constrastés d'encadrement des pratiques et des choix des enfants, Informations sociales, $\mathrm{n}^{\circ} 154$ : $80-87$.

Weber F (1995) L'ethnographie armée par les statistiques, Enquête (1): 153-165.

Weininger E and Lareau A (2003) Translating Bourdieu into the American context: the question of social class and family-school relations, Poetics: 375-402.

Willis P (1977) Learning to Labour: How Working Class Kids Get Working Class Jobs, Columbia University Press: New York. 